\title{
AN OUTLINE OF THE BIOLOGY, DISTRIBUTION, AND CONSERVATION \\ OF NERETVA NASE, CHONDROSTOMA KNERII (ACTINOPTERYGII: CYPRINIFORMES: CYPRINIDAE), ENDEMIC TO THE NERETVA RIVER BASIN (CROATIA AND BOSNIA AND HERZEGOVINA)
}

\author{
Pero TUTMAN ${ }^{1 *}$, Branko GLAMUZINA², Sanja MATIĆ-SKOKO ${ }^{1}$, Jakov DULČIĆ ${ }^{1}$, \\ Jerko PAVLIČEVIĆ ${ }^{3}$, and Adem HAMZIĆ ${ }^{4}$ \\ ${ }^{1}$ Institute of Oceanography and Fisheries, Split, Croatia \\ ${ }^{2}$ Department of Aquaculture, University of Dubrovnik, Dubrovnik, Croatia \\ ${ }^{3}$ Faculty of Agronomy and Food Technology, University of Mostar, Mostar, Bosnia and Herzegovina \\ ${ }^{4}$ Faculty of Science, Sarajevo, University of Sarajevo, Bosnia and Herzegovina
}

\begin{abstract}
Tutman P., Glamuzina B., Matić-Skoko S., Dulčić J., Pavličević J., Hamzić A. 2019. An outline of the biology, distribution, and conservation of Neretva nase, Chondrostoma knerii (Actinopterygii: Cypriniformes: Cyprinidae), endemic to the Neretva River basin (Croatia and Bosnia and Herzegovina). Acta Ichthyol. Piscat. 49 (2): 147-157.
\end{abstract}

\begin{abstract}
Background. The Neretva nase, Chondrostoma knerii Heckel, 1843, is an endemic cyprinid species distributed in the Neretva River basin in Croatia and Bosnia and Herzegovina, designated in the EU Habitats Directive as a species requiring conservation within member states. According to the IUCN, the species is catalogued as vulnerable (VU). Available scientific data indicate that significant aspects of its biological and ecological characteristics, as well as conservation requirements, are scarce and largely composed of outdated records.

This paper provides a summary of the main life history traits, particularly those related to the conservation challenges and a detailed list of the current state of knowledge.

Material and methods. This review was based on published literature in the form of research articles, monographs, books and technical reports, as well as unpublished data

Results. All available data were organized, critically analysed and presented in a comprehensive form. Issues related to species conservation were highlighted with respect to the impact of development activities. The longterm monitoring data of reproduction activity in the Hutovo Blato wetland were presented, showing the lowering of spring inflow capacity as the major factors for spawning success.

Conclusion. This review will, hopefully, serve as foundation and indicative example for future research aimed at better understanding the origin and status of this fish species in order to assure effective management and conservation programs.
\end{abstract}

Keywords: Podustva, Neretvan nase, Neretvian nase, Dalmatia nase Adriatic Sea watershed, biological-ecological traits, distribution, threats, conservation.

\section{INTRODUCTION}

It is widely known, that one of the important hotspots of the freshwater biodiversity in the Mediterranean covers the Neretva River basin of Croatia and Bosnia and Herzegovina (Mrakovcic et al. 1995, Crivelli 1996, Kottelat and Freyhof 2007, Buj et al. 2015), which belongs to the Adriatic Sea watershed. This area is characterized both by high biodiversity and a high percentage of endemic species. These species inhabit karstic freshwater ecosystems, that are also amongst the most vulnerable (Crivelli 1996) and very important in terms of local biodiversity. Due to the rapid decline in the quality of the environment caused by the construction of hydroelectric and water supply reservoirs, pollution, as well as the spreading of invasive species (Glamuzina et al. 2013), native species from this area require urgent conservation actions. However, the assessment of future development of their populations, as well as the risk of their extinction, can be hampered by many factors. That includes limited knowledge of the autecological requirements of the species' life history traits, their ecological niches, resource requirements, as well as the lack of suitable criteria to determine rarity (Burlakova et al. 2011).

"Correspondence: Dr P. Tutman, Institute of Oceanography and Fisheries, Laboratory for Ichthyology and Coastal Fisheries, Šetalište I. Meštrovića 63, 21000 Split, Croatia, phone++38521408030, e-mail (PT) tutman@izor.hr, (BG) branko.glamuzina@unidu.hr, (SMS) sanja@izor.hr, (JD)dulcic@izor.hr, (JP) pavlicevicj@gmail.com, (AH) haadem@hotmail.com. 
A typical example of such deficiency in our knowledge can be the Neretva nase, Chondrostoma knerii Heckel, 1843. This endemic freshwater fish species is geographically restricted to the middle and lower Neretva River catchment in Bosnia and Herzegovina and Croatia (Muus and Dahlström 1968, Elvira 1987, Kottelat 1997, Mrakovčić et al. 2006). Chondrostoma knerii is a medium-sized cyprinid species, reaching the maximum length of $29.4 \mathrm{~cm}$ (Glamuzina et al. 2007, Dulčić et al. 2009). Available data on the biology of this species is relatively scarce, although it has locally some commercial value for recreational fisheries, with highest prices during spawning season because of large and edible ovaries (Glamuzina et al. 2007). In common with other species of similar status (Tutman et al. 2016, 2018), attempts to develop an effective population management strategy have been obstructed by the deficiency of basic biological information (Tutman et al. 2012).

The use of biological and ecological trait-based approaches to address ecological problems is increasing (Mims et al. 2010) and can offer a framework for linking species traits to major environmental issues that influence its conservation (McGill et al. 2006). According to Maitland (2004), one of the major obstacles in assessing the threat to many fish species concerns the significant gaps in the knowledge regarding their biology. Consequently, the essential goal is to define species' biological and ecological traits as the basis for more effective protection (Economidis 2002).

Although the occurrence of this species has been reported for a long time (Heckel 1843), detailed and specific knowledge about it remains sparse. Hence, the Neretva nase has not been the object of systematic investigations, the scientific knowledge about population size, early development, recruitment, food and feeding is limited and scattered mostly in older literature. The available publications contain mainly overall faunistic records (Aganović 1952, Kosorić and Vuković 1966, Kosorić 1977, 1978, Kosorić et al. 1983, 1989, Šanda et al. 2008a, 2008b, Tutman et al. 2002, 2009, 2012) and general biological and ecological data (Vuković 1963, 1977, Vuković et al. 1970, Vuković and Ivanović 1971, Bogut et al. 2006, Mrakovčić et al. 2006, Kottelat and Freyhof 2007, Sofradžija 2009, Glamuzina et al. 2013).

Data about hybridization were presented by Vuković (1964). Some old data on the age structure are also available (Aganović and Kapetanović 1978). Furthermore, several papers have also been published on different life-history aspects like basic genetic (Berberović et al. 1970a, 1970b), serological issues (Guzina et al. 1971, Kaluđerčić et al. 1971, Berberović and Sofradžija 1972, Guzina and Vuković 1978), and internal anatomic characteristics (Vuković et al. 1970, Švob and Kilalić 1972, Vuković and Vuković 1974, Mikavica and Bošnjak 1989). Taxonomy and systematic position data were presented by Elvira $(1987,1997)$ and Kottelat (1997), while the general distribution and origin were given in Economidis and Banarescu (1991). General information regarding conservation status is presented in (Vuković and Sofradžija 1987, Crivelli 1996, Mikavica 1998, Tutman et al. 2002, 2008, Jelić et al. 2008, Zupančič 2008, Drešković et al. 2011). Despite the fact that surveys on taxonomy and phylogeny of endemic and rare cyprinids have more recently attracted considerable interest (Ketmaier et al. 2003, Bianco et al. 2004, Freyhof et al. 2005), data on the Neretva nase is rather scarce (Robalo et al. 2007, Perea et al. 2010). In particular, the general characteristics useful for fisheries management such as age, growth, and reproductive cycle have not been studied comprehensively. Some recent comparative studies have provided information on some biological and ecological characteristics and conservation status (Tutman et al. 2002, 2008), the population size structure, growth rate, reproductive aspects (maturation and spawning), and the length-weight relation (Glamuzina et al. 2007, Dulčić et al. 2009) for the population from the Hutovo Blato wetland in Bosnia and Herzegovina.

The purpose of this study was to highlight the knowledge gaps, which should be eliminated before any successful conservation measures are followed. There is also the urgent need for action in order to protect the freshwater fish species Chondrostoma knerii. Also, some conservation management recommendations are proposed in order to improve its natural status. This review was based on published literature in the form of research articles, books (Vuković 1963, 1977, Bogut et al. 2006), technical reports (Tutman et al. 2013, Glamuzina unpublished*, ), and unpublished data from personal experience of the authors of this paper. Additional data, including information on the main threats, were derived from different ichthyological monitoring surveys (Tutman et al. 2013, Glamuzina et al. unpublished*), and unpublished results of spawning activity monitored in the period 2010-2018 (Glamuzina, unpublished data). Problems and future perspectives for this valuable species in the Hutovo Blato wetland (Bosnia and Herzegovina), an important spawning and nursery ground are also discussed.

\section{TAXONOMY AND DISTRIBUTION}

Taxonomical status. Chondrostoma knerii is a species with valid taxonomical status (Elvira 1987, 1991, 1997); recent molecular phylogenetic studies based on the mitochondrial cytochrome $b$ gene included it in Italo-Balkanic lineage (Chondrostoma soetta clade) (Robalo et al. 2007).

Synonyms. Full list of synonyms was published by Elvira (1987)

Common names. Podustva (Croatia, Bosnia and Herzegovina); Neretvan nase, Neretvian nase, Neretva nase, Dalmatia nase (English).

Identification. See Fig. 1 for general appearance of the species representative. The Neretva nase was distinguished from its congeners in the western Balkans and Adriatic Sea watershed, such as Chondrostoma 
phoxinus Heckel, 1843; Chondrostoma nasus (Linnaeus, 1758); and Chondrostoma scodrense Elvira, 1987, by a combination of various characteristics listed in Vuković (1977), Kottelat and Freyhof (2007), and Sofradžija (2009): scales in lateral line 50-59; mouth arched and lower lip with thin cornified sheath; $1 / 27-8 / 1 / 5$ scales in transverse row between dorsal-fin and pelvic-fin origins; dorsal fin with 8-91/2 branched rays; and 19-24 gill rakers. Description. Body cylindrical, slender, and elongated, slightly laterally flattened. In adults body depth relatively large; small head with small mouth barely reaching anterior margin of eye. Eye colour yellowish in live individuals. Moderately large scales, very shiny in young fish, covering whole body. Snout thick and rounded, mouth semicircular and subterminal with characteristic thick and horn-like lower lip with sharp edge. Colouration greyish to brownish on back and silvery-white to slightly rosy on sides and abdomen; fins reddish, pale, or transparent. Longitudinal, grey line extending along flanks. Main meristic characters are as follows: D III/7-10(8): A III/9: V 11: P 15-16: C 19; Ll. scales (48) 52-54 (58), gill rakers: outer 20; inner 28, pharyngeal teeth 6-6, vertebrae 40-45 (Vuković 1977, Mrakovčić et al. 2006, Ćaleta et al. 2015). Males reaching $20.0-22.8 \mathrm{~cm}(n=352, \mathrm{TL}=14.0-22.8 \mathrm{~cm})(20.7-121.6$ $\mathrm{g})$; females up to $29 \mathrm{~cm}(25.4-228.6 \mathrm{~g})(n=372, \mathrm{TL}=$ 11.7-29.4 cm, Neretva River, Bosnia and Herzegovina) (Glamuzina et al. 2007).

Distribution. This species is endemic to the watercourses in the middle and lower Neretva River basin in Croatia and Bosnia and Herzegovina (Elvira 1987, Mrakovčić et al. 2006). The fish is rare in the upper river stretches (Vuković and Ivanović 1971). In Croatia, it is distributed in the lower Neretva River basin area (rivers Neretva, Crna rijeka, Norin and lakes Modro oko, Desne, and Baćinska jezera) (Mrakovčić et al. 2006). The population from the Zadar area (probably in a small river close to Zrmanja), noted by Elvira (1987), as well as from the Cetina River (Croatia), has disappeared (Mrakovcic et al. 1995). In Bosnia and Herzegovina, it is distributed in middle and lower Neretva River drainage area (Neretva River and its tributaries Buna, Bregava, Krupa, Trebižat, and Hutovo
Blato wetland) (Vuković 1977, Kosorić 1978, Kosorić et al. 1983) (Fig. 2). However, the species does not occur in the reservoirs in the middle and upper Neretva.

\section{BIOLOGY AND ECOLOGY}

Habitat. In the Neretva River drainage system this rheophilic species prefers habitats with a medium fast flow and relatively cool water $\left(15-17^{\circ} \mathrm{C}\right)$, mainly the middle and lower parts of the river. Vuković and Ivanović (1971) and Vuković (1977) mentioned its occurrence in the upper river areas as rare, however there are no recent data to confirm this (Glamuzina et al. 2013) the main populations of this species occur in water bodies of low plains, especially in Hutovo Blato wetland, where currents are slow. Outside the spawning period, the species lives in smaller schools (Vuković 1977), while one part of the year it lives in the karstic underground.

General biology. Age analyses of the populations estimated longevity at 7.5 years; males $5+$ and females $7+$ years. The most abundant age classes were the 3-3+ (40\%), 4-4+ $(32 \%)$, and $5-5+(19 \%)$ classes. Overall sex ratio $0.95 \div 1$ in favour of females $(n=724 ; 352$ males and 372 females, Hutovo Blato wetland, Neretva River) (Glamuzina et al. 2007). The parameters of the allometric length-weight relation (LWR; $\log W=\log a+b \log L ; n=424$, size range 11.7-29.4 cm TL, both sexes) estimated by Dulčić et al. (2009) were $a=0.0035$ (0.0010-0.0060), $b=3.27$ (3.09 $3.53)$, and the correlation coefficient $r^{2}=0.9360$. The feeding mode is described as predominately omnivorous, mostly feeding on periphyton, but also consuming small aquatic benthic invertebrate fauna (Vuković 1977, Mrakovčić et al. 2006, Sofradžija 2009, Glamuzina et al. 2013).

Spawning. Neretva nase breeds from January to April; spawners undertake spawning migrations in large schools from the Neretva River to the Hutovo Blato wetland, which seems to be the main spawning area, and return thereafter to the main river where reproduction occurs in streams with the high water flow velocity. Spawning starts in mid-February in the springs, at a water temperature of approx. $13^{\circ} \mathrm{C}$. The mean ovary weight is $14.37 \mathrm{~g}$, varying from 5.9 to $35.2 \mathrm{~g}$, which equals $4 \%$ to $62 \%$ of the total body weight (mean

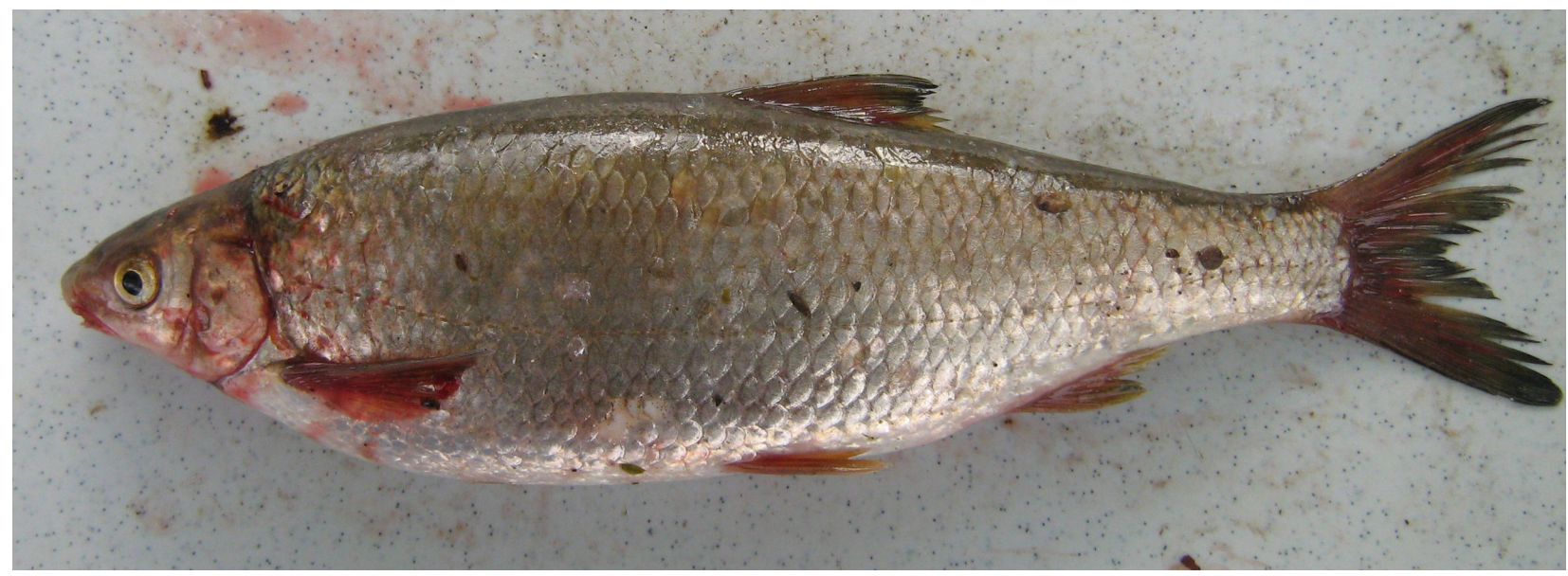

Fig. 1. Neretva nase, Chondrostoma knerii, $29 \mathrm{~cm}$ TL from the lower Neretva River, Bosnia and Herzegovina (Photo by Pero Tutman, October 2012) 
$=21.77 \%$ ). The gonadosomatic index (GSI) distribution shows an inverse proportionality with total length (Glamuzina et al. 2007). The most frequent length classes for reproduction range from 20 to $24 \mathrm{~cm}$, while fecundity ranges between 2000 and 16000 eggs per female, with the mean value of 7000 eggs (Glamuzina et al. 2007). However, there are published data which provide a fecundity between 8000 and 40000 eggs (Sofradžija 2009). The colour of ovaries changes from brown to orange-red as they mature and the spawning time approaches. The egg consistency also changes from hard (brown colour) to soft (orangered colour). The species is a non-guarder, with the eggs being released by the female above the substrate. Spawned eggs are soft, orange-red and sticky, found in streams of high water flow velocity. Eggs are attached to the various substrates such as aquatic plants or solid objects (i.e., gravel, stones, submerged wood). In addition, eggs are found deposited in shallow waters of springs with high water flow velocities. Fast flowing conditions seem to be a prerequisite for successful spawning and embryo development, as can also be observed in other Chondrostoma species (Keckeis 2001). The eggs in springs with appropriate water flow velocities are developed well and hatched successfully. The mean egg diameter is $1.78 \pm 0.72 \mathrm{~mm}$ (range: $1.51-2.16$ $\mathrm{mm}$ ). The correlation between egg number and length and weight is low $\left(r^{2}=0.959\right)$. The number of eggs is positively correlated with gonad weight (Glamuzina et al. 2007).

The Neretva nase population in the Hutovo Blato wetland spawns exclusively in springs around the Londža spring area including Big and Small Smokovac (Babino oko), Londža (several springs) and Gabeokino springs (Fig. 3). The eggs are usually found in the late February/beginning of March in the Londža spring complex, attached to aquatic plants, stones, or other substrates, such as fish traps. The hatched larvae are firstly noticed at the beginning of March; while the first metamorphosed juveniles (Fig. 4) are found at the end of March (30 March), showing that the larval period roughly lasts for one month when the water temperature is relatively constant, between 12.7 and $13.2^{\circ} \mathrm{C}$. At high water level conditions during March (years 2010, 2013, and 2018) the larvae were observed around Londža Stream in shallow areas of flooded meadows and even at a flooded concrete road (Fig. 5). This area is characterized by a favourable temperature $\left(16^{\circ} \mathrm{C}\right)$ and is rich in zooplankton upon which larvae and juveniles feed. During April small juveniles start to migrate to the larger Deran Lake (Glamuzina, unpublished data). A small number of juveniles remain throughout the year in the Hutovo Blato wetland, especially in cold streams. These observations point to the importance of this area as a vital nursery ground. At the age of two years, the young fish migrate to the Neretva River (Glamuzina et al. unpublished*).

\section{CURRENT STATUS, THREATS, USES}

Population status. Population decrease has been observed since the 1970s, mainly caused by hydrological changes in Neretva River regime, degradation of spawning habitats, and introduction of competitive and non-native and invasive fish species. Moreover, the population from Zrmanja and Cetina rivers (Croatia) is probably extinct (Mrakovcic et al. 1995). Within its distribution area, the nase populations can be sporadically numerous in some locations, especially in cold streams during the spawning season, such as in the Hutovo Blato wetland, where it represented $30 \%$ of the total fish abundance (Glamuzina et al. unpublished*). However, after the spawning season in

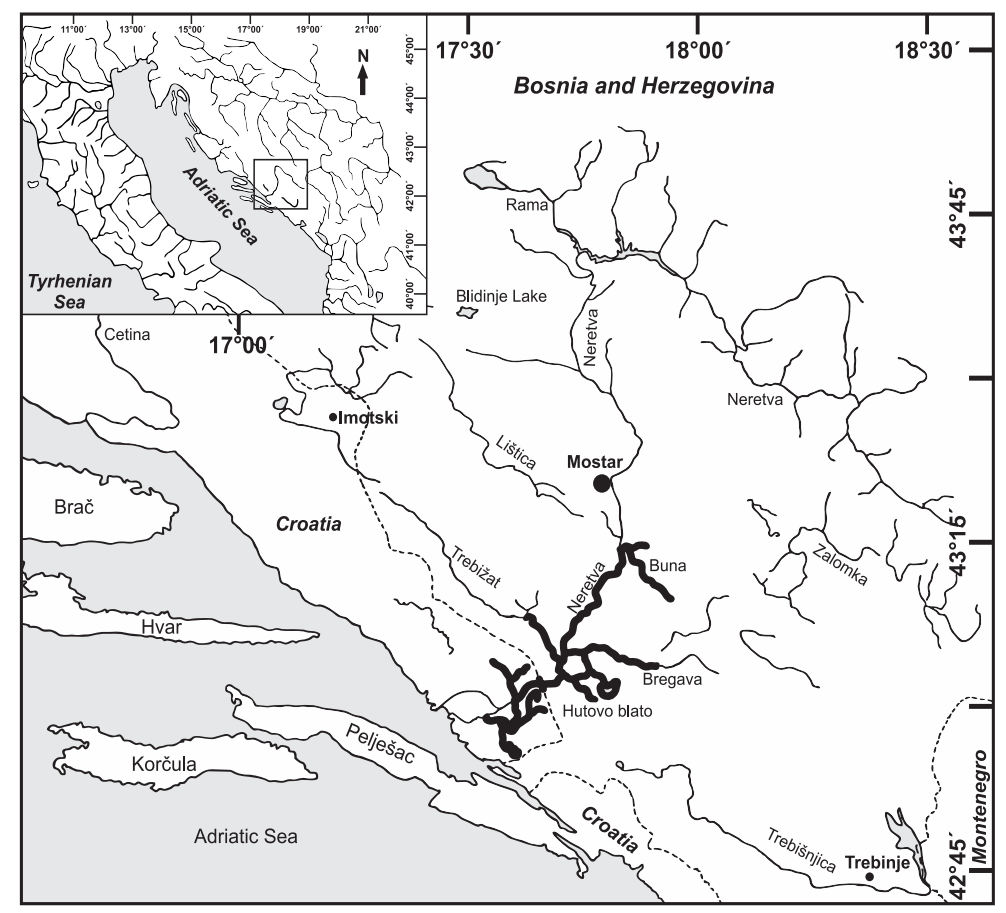

Fig. 2. Distribution map of the Neretva nase, Chondrostoma knerii (thick black lines) in the Adriatic Sea watershed 


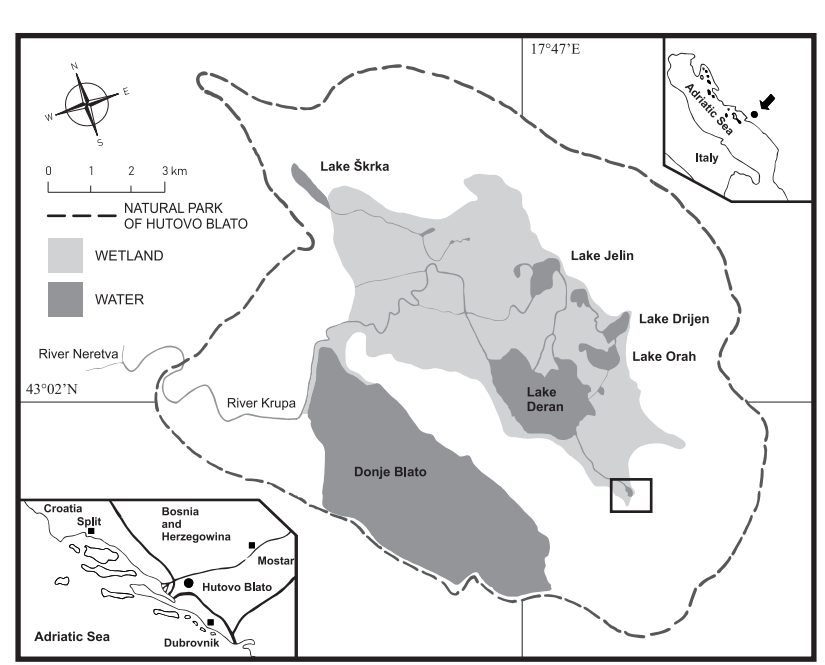

Fig. 3. The Neretva nase, Chondrostoma knerii, population in Hutovo Blato wetland spawn exclusively in springs around Londža spring area (black rectangle)

the Hutovo Blato the population becomes less numerous. There is no precise data about future population trend estimates available in the literature. In the past, $C h$. knerii was abundant along its distribution area, but during the last two decades, the population size and distribution area have declined (Glamuzina et al. 2007). Formerly, it was relatively widely distributed in the middle and especially the lower Neretva River (Vuković 1971). During the 1970s the species was relatively abundant in the Hutovo Blato wetland, contributing up to $26 \%$ of the local fish community (Kosorić 1978). Furthermore, in the middle Neretva River, Aganović and Kapetanović (1978) reported catch of Neretva nase constituting $54.54 \%$ of the total catch. However, Kosorić (1978) has reported on its declining numbers since the introduction of carp in the waters of Hutovo Blato wetland.
Threats. Despite the apparent decline of the species in the last decades (Glamuzina et al. 2007), it is evident that a great deal of general knowledge concerning threats remains still largely unknown. The changing course of the Neretva River in the upper streams and the presence of invasive alien fish species have both been recognized as the main factors influencing species survival (Tutman et al. 2008, 2013, Pavličević et al. 2016, Glamuzina et al. 2017, Glamuzina et al. unpublished*). In this regard, the loss of environmental quality relating to hydrological changes in the Neretva River catchment brought about by lower spring flows and general water level lowering in the Hutovo Blato wetland has lead to decreased spawning success (Glamuzina et al. 2007). We believe that these changes (lower spring discharge, lower water level during the season) represent the main threat to survival for Neretva nase. Several times during the spawning seasons of the last two decades, Neretva nase failed to spawn in the majority of springs. Monitoring surveys conducted from 2010 through 2018 clearly showed that high water levels and flooding of nearby meadows resulted in a high survival rate and fast growing recruits. This was the case in 2010, 2013, and 2018. The flooding conditions in these specific years resembled the historical hydrological situation before the construction of the hydro-energetic system in the upper sections of the Neretva River, which has modified the water flow. In the years with low water influx into the springs, the survival of early stages was low. The most obvious effect was egg mortality due to exposure of eggs to air conditions due to water level fluctuations during the incubation period. Furthermore, an additional problem is the deterioration in water quality in many streams connecting the springs and lakes of the area. Significant numbers of springs are clogged with plant overgrowth, causing local flooding and preventing any fish migration toward the springs, in addition to significantly lowering the water flow velocity, an important factor

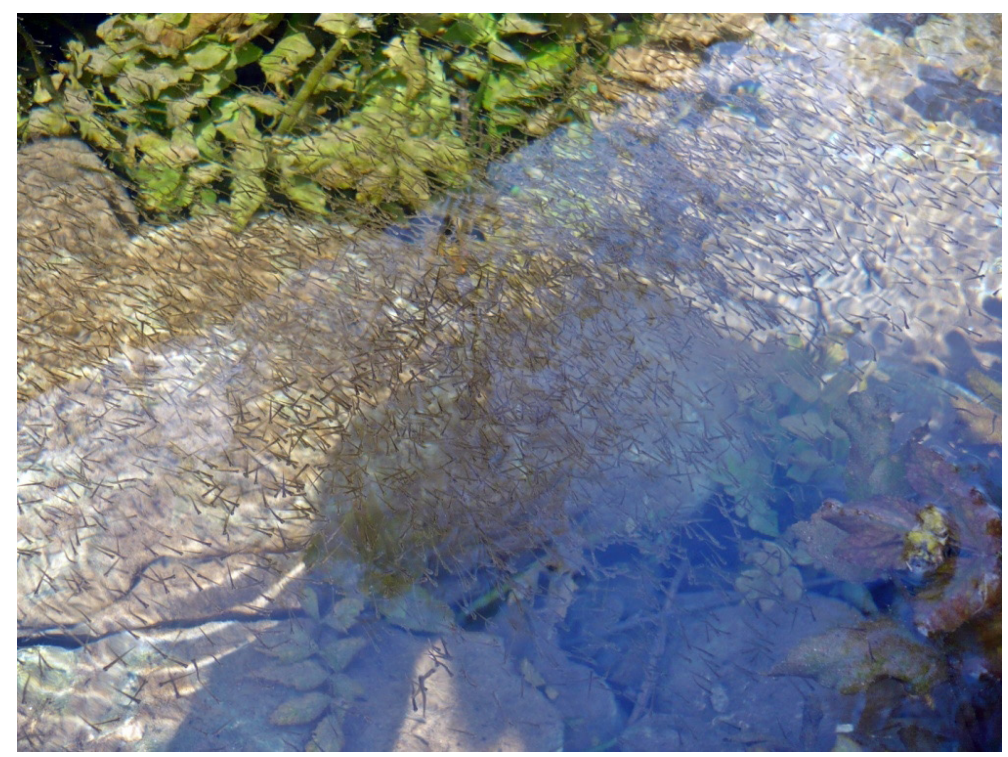

Fig. 4. Larvae school of the Neretva nase, Chondrostoma knerii, grouped on flooded meadows (Photo by Branko Glamuzina, April 2013) 
for successful reproduction of the species. One adverse effect of the clogged streams on the reproduction is the decrease in dissolved oxygen due to the decomposition of plant matter (Glamuzina et al. 2007). Furthermore, the future development of the hydro-energetic project named "Gornji horizonti" (The Upper Horizons), which will divert a significant amount of water from the Hutovo Blato wetland, is of significant concern. The hydrological impact of this project will further endanger the spawning success in this area and make the Neretva nase more vulnerable to extinction. In addition, invasive species, such as Lepomis gibbosus (Linnaeus, 1758) and Gymnocephalus cernua (Linnaeus, 1758), cause a decrease in the population of Neretva nase in the Hutovo Blato wetland by predating the recruits (Glamuzina et al. 2007), while sander, Sander lucioperca (Linnaeus, 1758) (see Pavličević et al. 2016) and other predator invasive species (Glamuzina et al. 2017 ) in major Neretva flows have a significant impact on the adult life stages of the species.

Use and trade. Neretva nase is a species locally known for its tasty flesh, especially in the Hutovo Blato wetland area, Bosnia and Herzegovina. It has also commercial value for recreational fisheries and artisanal fishers because of its large and edible ovaries (Glamuzina et al. 2007). The species is consumed fresh and smoked by the local population.

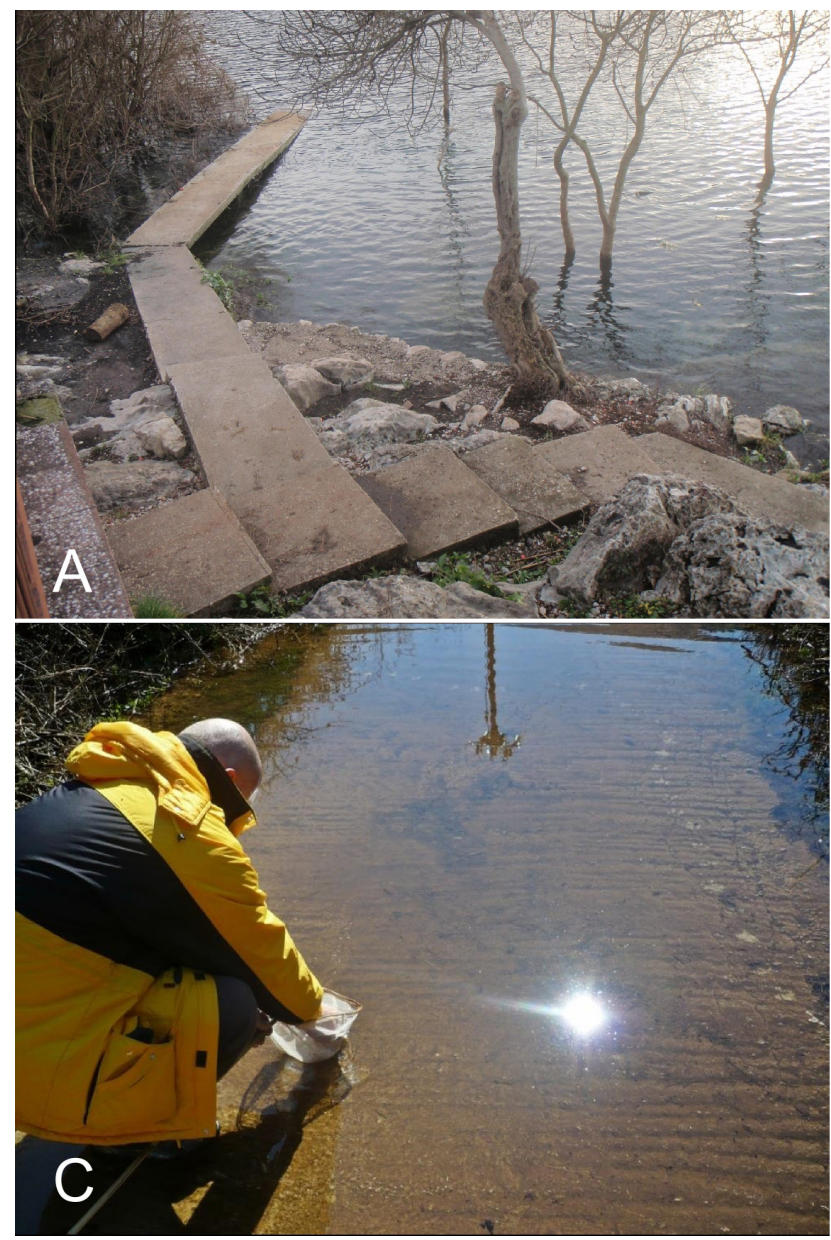

\section{CONSERVATION}

Conservation status. Recently the species was classified as vulnerable (VU) (Crivelli 2006). Furthermore, the species is listed in the Annex II of the Directive 92/43/ EEC (Anonymous 1992). The Directive considers that species populations are threatened by habitat degradation due to human activities. It is listed in Appendix III of the Bern Convention (Anonymous 1982). However, it is considered as endangered (EN) for Croatian waters in the Red Book of freshwater fishes (Mrakovčić et al. 2006), as well as in the Red List of fauna of Federation of Bosnia and Herzegovina as part of Bosnia and Herzegovina (Škrijelj et al. 2013). It is suggested to revise the species status into endangered due to the rapid decline of its stocks observed over the two last decades in both, Croatia and Bosnia and Herzegovina.

Conservation actions. The Neretva nase is proclaimed as a strictly protected species in Croatia (Anonymous 2008), although no conservation actions have ever been implemented; in Bosnia and Herzegovina, it remains unprotected. The lower Neretva River delta in Croatia has been declared a special ornithological and ichthyological reserve, although no conservation actions have been implemented. The same situation applies to Bosnia and Herzegovina where the Hutovo Blato wetland was

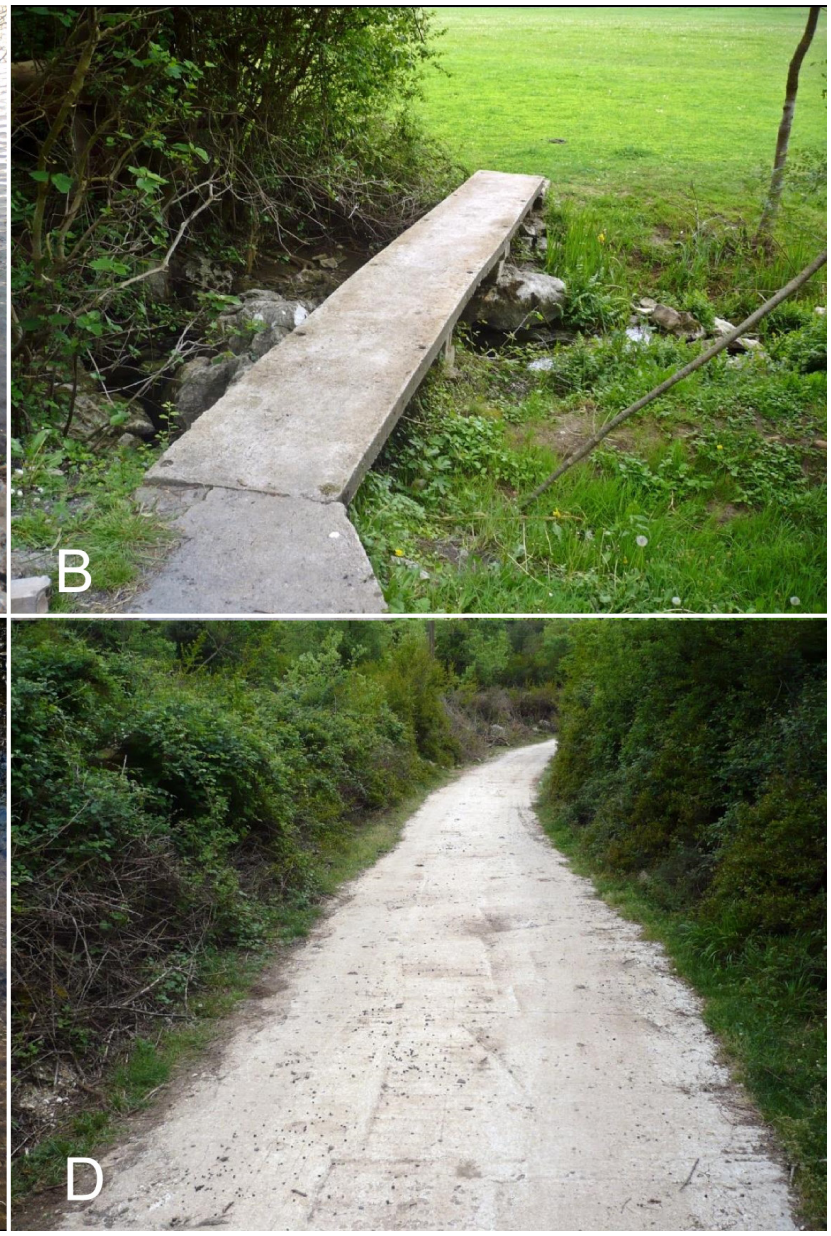

Fig. 5. The major spawning ground of the Neretva nase, Chondrostoma knerii, in the Hutovo Blato wetland; conditions of high water (A, C) and conditions of dry years (B, D); photo by Branko Glamuzina (A and C, March 2013; B and D, March 2014) 
declared a Nature park in 1995, and a Ramsar Site in 2001. Taking into account the conservation issues reported for this species, there is an imperative to restore the historical discharge and flooding schemes, as a basis for taking security measures to enhance the species survival.

Conservation recommendations. The effects of conservation management on population dynamics depend on the knowledge of the environmental requirements and the biological characteristics of the fish. Therefore, improved water management practice in the Hutovo Blato wetland is necessary, along with habitat protection aimed at initiating or restoring natural processes (i.e., increased floods, increased flow-velocities) and improving natural habitat conditions in spawning sites. It is also crucial to reduce the impact of invasive species, as well as to prohibit fishing during the spawning period in order to minimize the consumption of large individuals with large ovaries for the protection of the species. Therefore, improved fisheries regulations are recommended (Glamuzina et al. 2007). Other potential spawning grounds (the Bunica River in Bosnia and Herzegovina and the Norin River in Croatia) should also be investigated as suitable habitats with favourable water flow velocity (Glamuzina, unpublished data). Finally, a long-term programme is needed for population monitoring along with further studies aiming at the assessment of impacts caused by changes in the hydrological regimes. In order to preserve and enhance the status of the Neretva nase there is an urgent need for a targeted rehabilitation programme. Moreover, the implementation of a specific code of practice is strongly recommended. To conserve these populations appropriate management policies are necessary to target the specific requirements of the populations before they reach the status of being threatened or endangered.

\section{DISCUSSION}

In the watershed of the Adriatic Sea, the majority of main rivers and lakes are transboundary, creating conflicts of interest since water resources are unevenly distributed among the countries. There is a strong need for coordination in river management issues, such as pollution control, hydroelectric energy production, and the control of alien fishes. Studies such as this presented here are therefore important in compiling a baseline reference source for establishing management measures and policies for the conservation of threatened and rare freshwater fish species, as referred in Maitland (2004).

The current study has revealed the true extent of the gaps in the knowledge of the current state, distribution and impacts for Neretva nase in the study area. These gaps should be targeted through coordinated research that could assist in effective conservation efforts. This study forms a valuable platform in gathering basic biological and ecological information and especially threats and conservation challenges, which have been encountered. One of the first tasks in preparing conservation plans for the fish fauna should be a proper assessment of the conservation status of the species involved. This is essential for prioritising those species under greatest threat and for the preparation of conservation management plans (Maitland 2004). The current information indicates that there have been considerable changes in the distribution and abundance of Ch. knerii in the waters of the Neretva basin since the 1970s. Before the construction of hydropower dams, Neretva nase probably also inhabited the upper part of the Neretva River catchment. However, after dam construction, the species is not recorded in middle and upper Neretva reservoirs, most probably due to its less adaptive nature, since it has not adapted to the new living conditions in the impoundments.

The Neretva nase is a species which periodically migrates in large numbers during the spawning season, while in the rest of the year such migration was not often recorded. The Hutovo Blato wetland is recognized as the main spawning and nursery ground for this species. Migration is a feature of the life cycle of many fish species, and at migration times they may be particularly vulnerable. The major threat found for Neretva nase is the low water level and the altered discharge regime from hydropower facilities which drastically reduces the spawning success. As a consequence of these changes, the spawning areas fall dry. Migratory fish species like the Neretva nase may serve as an indicator species, as the decline of the populations is linked to environmental perturbations (Economidis 2002). Knowledge of the main threats recognised, as well as bio-ecological history, have great importance for its conservation since it enables the prediction of its future trend and an estimation of its survival probability.

Although some legislation in relation to various general aspects of conservation (such as the establishment of nature reserves) exist, very little or no of these activities have been aimed directly on the protection of the Neretva nase or other endemic species. This situation must be improved if further populations are to be protected from extinction. We consider that the results of this study may have important implications for conservation by providing data on the ecology and population structure of this poorly known species in an amended environment. Finally, we recommend that a greater effort should be made towards fieldwork for collecting data. There also needs to be more studies on the main threats to species survival in the Hutovo Blato area. Moreover, changes in the sea level with the consequent increased risk of flooding, erosion, and salinization of coastal lowlands and estuaries (Handisyde et al. 2006) can cause further alterations in the balance of aquatic systems which host strictly endemic species with highly localized distributions.

\section{ACKNOWLEDGEMENTS}

We are thankful to Nikola Zovko (Director, Nature Park Hutovo Blato, Bosnia and Herzegovina), for his generous support during the investigation and to Jason Kirby form Liverpool John Moores University, UK, for improving the English in the manuscript. 


\section{REFERENCES}

Aganović M. 1952. Hutovo Blato. Ribarstvo Jugoslavije 3 (1): 28-30. [In Serbo-Croatian/Croato-Serbian.]

Aganović M., Kapetanović N. 1978. Uzrasna struktura u populacijama nekih vrsta riba iz rijeke Neretve. [The age structure in the populations of some fish species from the Neretva River.] Ichthyologia 10 (1): 1-7. [In Serbo-Croatian/Croato-Serbian.]

Anonymous 1982. The Bern Convention on the Conservation of European Wildlife and Natural Habitats. ETS No.104. (01.06.1982).

Anonymous 1992. Council Directive 92/43/EEC on the Conservation of natural habitats and of wild fauna and flora. Official Journal of the European Communities No L 206/7 (22.7.92).

Anonymous 2008. Zakon o zaštiti prirode. [Law of Nature Protection.] Narodne novine br. 70/05 i 139/08. [The People's Newspaper No. 70/05 and 139/08.]

Berberović Lj., Hadžiselimović R., Sofradžija A. 1970a. Uporedni pregled osnovnih podataka hromozomskim garniturama vrsta Chondrostoma phoxinus Heckel i Chondrostoma knerii Heckel. [Comparative review of the basic data on the chromosome complements of Chondrostoma phoxinus Heckel and Chondrostoma knerii Heckel.] Ichthyologia 2 (1): 25-30. [In SerboCroatian/Croato-Serbian.]

Berberović Lj., Hadžiselimović R., Sofradžija A. 1970b. Komparativna analiza hromosomskih garnitura podbile (Chondrostoma phoxinus Heckel) i podustve (Chondrostoma kneri Heckel). [Comparative analysis of Minnow-nase Chondrostoma phoxinus Heckel) and Neretvan nase (Chondrostoma kneri Heckel) chromosome sets.] P. 8. In: 3. Simpozij "Savremena ihtiološka istraživanja u Jugoslaviji” (Kotor), Abstrakti. [In Serbo-Croatian/Croato-Serbian.]

Berberović Lj., Sofradžija A. 1972. Pregled podataka o hromosomskim garniturama slatkovodnih riba Jugoslavije. [Review of data on the chromosome of freshwater fish of Yugoslavia.] Ichthyologia 4 (3): 1-21. [In Serbo-Croatian/Croato-Serbian.]

Bianco P.G., Aprea G., Balletto E., Capriglione T., Fulgione D., Odierna G. 2004. The karyology of the cyprinid genera Scardinius and Rutilus in southern Europe. Ichthyological Research 51 (3): 274-278. DOI: 10.1007/s10228-004-0221-y

Bogut I., Novoselić D., Pavličević I. 2006. Biologija riba. [Biology of Fishes.] Poljoprivredni fakultet u Osijeku. Osijek, Croatia. [In Croatian.]

Buj I., Ćaleta M., Marčić Z., Šanda R., Vukić J., Mrakovčić M. 2015. Different histories, different destinies-Impact of evolutionary history and population genetic structure on extinction risk of the Adriatic spined loaches (Genus Cobitis; Cypriniformes, Actinopterygii). PLoS ONE 10 (7): e0131580. DOI: 10.1371/journal.pone. 0131580

Burlakova L.E., Karatayev A.Y., Karatayev V.A., May M.E., Bennett D.L., Cook M.J. 2011. Endemic species: Contribution to community uniqueness, effect of habitat alteration, and conservation priorities.
Biological Conservation 144 (1): 155-165. DOI: 10.1016/j.biocon.2010.08.010

Crivelli A.J. 1996. The freshwater fish endemic to the northern Mediterranean region. An action plan for their conservation. Tour du Valat Publication, Arles, France.

Crivelli A.J. 2006. Chondrostoma knerii. The IUCN Red List of Threatened Species 2006: e.T4788A11094572. [Downloaded on 13 December 2018.] DOI: 10.2305/ IUCN.UK.2006.RLTS.T4788A11094572.en

Ćaleta M., Buj I., Mrakovčić M., Mustafić P., Zanella D., Marčić Z., Duplić A., Mihinjač T., Katavić I. 2015. Endemic fishes of Croatia. Croatian Environment Agency, Zagreb, Croatia.

Drešković N., Đug S., Stupar V., Hamzić A., Lelo S., Muratović E., Lukić-Bilela L., Brujić J., Milanović Đ., Kotrošan D. 2011. NATURA 2000 u Bosni i Hercegovini. [NATURA 2000 in Bosnia and Herzegovina.] Centar za okolišno održivi razvoj Sarajevo, Bosnia and Herzegovina. [In Bosnian.]

Dulčić J., Tutman P., Prusina I., Tomšić S., Dragičević B., Hasković E., Glamuzina B. 2009. Length-weight relationships for six endemic freshwater fishes from Hutovo Blato wetland (Bosnia and Herzegovina). Journal of Applied Ichthyology 25 (4): 499-500. DOI: 10.1111/j.1439-0426.2009.01291.x

Economidis P.S. 2002. Biology of rare and endangered non-migratory fish species: Problems and constraints. Pp. 81-89. In: Collares-Pereira M.J., Coelho M.M., Cowx I.G. (eds.) Conservation of freshwater fishes: Options for the future. Blackwell Science. Fishing News Book, Oxford, London.

Economidis P.S., Banarescu P.M. 1991. The distribution and origins of freshwater fishes in the Balkan Peninsula, especially in Greece. Internationale Revue der gesamten Hydrobiologie und Hydrographie 76 (2): 257-283. DOI: 10.1002/iroh.19910760209

Elvira B. 1987. Taxonomic revision of the genus Chondrostoma Agassiz, 1835 (Pisces, Cyprinidae). Cybium 11 (2): 111-140.

Elvira B. 1991. Further studies on the taxonomy of the genus Chondrostoma (Osteichthyes, Cyprinidae): Species from eastern Europe. Cybium 15 (2): 147-150.

Elvira B. 1997. Taxonomy of the genus Chondrostoma (Osteichthyes, Cyprinidae): An updated review. Folia Zoologica 46 (Suppl. 1): 1-14.

Freyhof J., Lieckfeldt D., Pitra C., Ludwig A. 2005. Molecules and morphology, evidence for introgression of mitochondrial DNA in Dalmatian cyprinids. Molecular Phylogenetics and Evolution 37 (2): 347 354. DOI: 10.1016/j.ympev.2005.07.018

Glamuzina B., Bartulović V., Dulčić J., Conides A.J., Tutman P., Matić-Skoko S., Gavrilović A., JugDujaković J., Hasković E., Ivanc A., Zovko N. 2007. Some biological characteristics of the endemic Neretvan nase, Chondrostoma knerii Heckel, 1843, in the Hutovo Blato wetlands (Bosnia and Herzegovina). Journal of Applied Ichthyology 23 (3): 221-225. DOI: 10.1111/j.1439-0426.2006.00828.x 
Glamuzina B., Pavličević J., Tutman P., Glamuzina L., Bogut I., Dulčić J. 2013. Ribe Neretve. [Fishes of the Neretva River.] CEAV, Mostar, Bosnia and Herzegovina and Modrozelena, Metković, Croatia. [In Croatian.]

Glamuzina B., Tutman P., Nikolić V., Vidović Z., Pavličević J., Vilizzi L., Copp G.H., Simonović P. 2017. Comparison of taxon-specific and taxon-generic risk screening tools to identify potentially invasive nonnative fishes in the River Neretva catchment (Bosnia and Herzegovina and Croatia). River Research and Applications 33 (5): 670-679. DOI: 10.1002/rra.3124

Guzina N., Vuković T. 1978. Serološka proučavanja nekih vrsta ciprinida iz voda Bosne i Hercegovine. [Serologic investigation of some cyprinid species from Bosnia and Herzegovina freshwaters.] Ichthyologia 10 (1): 55-65. [In Serbo-Croatian/Croato-Serbian.]

Guzina N., Vuković T., Miladinović Ž. 1971. Serološka istraživanja nekih vrsta riba iz familije Salmonidae i Cyprinidae (Pisces) iz voda jadranskog sliva u Bosni i Hercegovini. [Serologic investigations of some salmonid and cyprinid species from Adriatic watershed in Bosnia and Herzegovina.] In: I Simpozijum biosistematičara Jugoslavije. Zbornik radova, Sarajevo, Yugoslavia. [In Serbo-Croatian/ Croato-Serbian.]

Handisyde N.T., Ross L.G., Badjeck M.C., Allison E.H. 2006. The effects of climate change on world aquaculture: A global perspective. Final technical report, Department for International Development, Stirling Institute of Aquaculture, Stirling, UK.

Heckel J.J. 1843. Ichthyologie. Pp. 991-1099. In: Russegger J. (ed.) Reisen in Europa, Asien und Afrika, mit besonderer Rücksicht auf die naturwissenschaftlichen Verhältnisse der betreffenden Länder, unternommen in den Jahren 1835 bis 1841. Erste Band. Reise in Griechenland, Unteregypten, im nördlichen Syrien und südöstlichen Kleinasien. Zweiter Theil. Mit 2 Karten von Taurus, 1 Blatt mit Gebirgs-Durchschnitten, 20 botanischen und 15 zoologischen Tafeln. E. Schweizerbart'sche Verlagshandlung, Stuttgart, Kingdom of Württemberg. DOI: 10.5962/bhl.title.35097

Jelić D., Duplić A., Ćaleta M., Žutinić P. 2008. Endemske vrste riba jadranskog sliva. [Endemic fish of the Adriatic drainage.] AZO-Agencija za zaštitu okoliša, Zagreb, Croatia. [In Croatian.]

Kaluđerčić M., Kaluđerčić D., Kosorić Đ., Pavlić S., Vuković T. 1971. Serum proteini krvi nekih slatkovodnih riba Bosne i Hercegovine. [Serum blood protein of some freshwater fish of Bosnia and Herzegovina.] Ichthyologia 3 (1): 37-48. [In SerboCroatian/Croato-Serbian.]

Keckeis H. 2001. Influence of river morphology and current velocity conditions on spawning site selection of Chondrostoma nasus (L.). Archiv für Hydrobiologie; Supplement to 135 (2-4) [Large Rivers 12 (2-4)]: 341-356. DOI: 10.1127/lr/12/2001/341
Ketmaier V., Bianco P.G., Cobolli M., De Matthaeis E. 2003. Genetic differentiation and biogeography in southern European populations of the genus Scardinius (Pisces, Cyprinidae) based on allozyme data. Zoologica Scripta 32 (1): 13-22. DOI: 10.1046/j.14636409.2003.00099.x

Kosorić Đ. 1977. Populacije riba srednje Neretve, sa projekcijom razvojnih mogućnosti poslije izgradnje vodenih akumulacija. [The fish populations of the middle part of the Neretva River, with projection of spreading possibilities after water reservoir construction.] Ichthyologia 9 (1): 121-129. [In SerboCroatian/Croato-Serbian with English summary.]

Kosorić Đ. 1978. Sastav populacije riba Hutova blata. [The composition of the Hutovo Blato fish population.] Godišnjak BIUS 31: 69-81. [In Serbo-Croatian/ Croato-Serbian.]

Kosorić Đ., Vuković T. 1966. Ribe rijeke Bune. [Fishes of the Buna River.] Glasnik Zemaljskog muzeja Bosne i Hercegovine u Sarajevu. Prirodne nauke 5 (2): 179 190. [In Serbo-Croatian/Croato-Serbian.]

Kosorić Đ., Vuković T., Guzina N., Kapetanović N., Mikavica D. 1989. Ihtiofauna rijeke Neretve i njene promjene posljedično izgradnji hidroelektrana. [Ichthyofauna of the Neretva River and its changes after the building of hydroelectricity power stations.] Pp. 133-138. In: Zbornik radova - Savjetovanje o ribarstvu na hidroakumulacijama. Mostar, Yugoslavia. [In Serbo-Croatian/Croato-Serbian.]

Kosorić Đ., Vuković T., Kapetanović N., Guzina N., Mikavica D. 1983. Sastav populacija riba rijeke Neretve u Bosni i Hercegovini. [The composition of fish population of the Neretva River in Bosnia and Herzegovina.] Godišnjak BIUS 36: 117-128. [In Serbo-Croatian/Croato-Serbian.]

Kottelat M. 1997. European freshwater fishes. Biologia 52 (Suppl. 5): 1-271.

Kottelat M., Freyhof J. 2007. Handbook of European freshwater fishes. Publications Kottelat, Cornol and Freyhof, Berlin.

Maitland P.S. 2004. Ireland's most threatened and rare freshwater fish: An international perspective on fish conservation. Biology and Environment: Proceedings of the Royal Irish Academy 104B (3): 5-16. DOI: 10.3318/BIOE.2004.104.3.5

McGill B.J., Enquist B.J., Weiher E., Westoby M. 2006. Rebuilding community ecology from functional traits. Trends in Ecology and Evolution 21 (4): 178-185. DOI: $10.1016 /$ j.tree.2006.02.002

Mikavica D. 1998. The specific freshwater ichthyofauna of the hydrographic region of Bosnia and Herzegovina. Ichthyologia 30 (1): 15-30.

Mikavica D., Bošnjak Ž. 1989. Morfološke karakteristike digestivnog trakta nekih vrsta riba iz roda Chondrostoma. [Morphological characteristics of digestive tract of some species of fish from the genus Chondrostoma.] Ichthyologia 21 (1): 7-16. [In SerboCroatian/Croato-Serbian.] 
Mrakovčić M., Brigić A., Buj I., Ćaleta M., Mustafić P., Zanella D. 2006. Crvena knjiga slatkovodnih riba Hrvatske. [Red Book of freshwater fish of Croatia.] Ministarstvo kulture, Državni zavod za zaštitu prirode, Republika Hrvatska. [Ministry of Culture, State Institute for Nature Protection, Republic of Croatia.] Zagreb, Croatia. [In Croatian.]

Mrakovcic M., Misetic S., Povz M. 1995. Status of freshwater fish in Croatian Adriatic river systems. Biological Conservation 72 (2): 179-185. DOI: 10.1016/0006-3207(94)00080-A

Mims M.C., Olden J.D., Shattuck Z.R., Poff N.L. 2010. Life history trait diversity of native freshwater fishes in North America. Ecology of Freshwater Fish 19 (3): 390-400. DOI: 10.1111/j.1600-0633.2010.00422.x

Muus B.J., Dahlström P. 1968. BLV Bestimmungsbuch Süßwasserfische - Europas, in Farben abgebildet und beschrieben Biologie, Fang, wirtschaftliche Bedeutung. BLV Verlagsgesellschaft, München, Germany.

Pavličević J., Glamuzina L., Conides A., Savić N., Rozić I., Klaoudatos D., Kazić A., Glamuzina B. 2016. Pikeperch, Sander lucioperca invasion in the Neretva River watershed (Bosnia and Herzegovina, Croatia) after alteration of river flow. River Research and Applications 32 (5): 967-974. DOI: 10.1002/ rra.2923

Perea S., Böhme M., Zupančič P., Freyhof J., Šanda R., Özuluğ M., Abdoli A., Doadrio I. 2010. Phylogenetic relationships and biogeographical patterns in circumMediterranean subfamily Leuciscinae (Teleostei, Cyprinidae) inferred from both mitochondrial and nuclear data. BMC Evolution Biology 10: e265. DOI: 10.1186/1471-2148-10-265

Robalo J.I., Carvalho Almada V., Levy A., Doadrio I. 2007. Re-examination and phylogeny of the genus Chondrostoma based on mitochondrial and nuclear data and the definition o 5 new genera. Molecular Phylogenetics and Evolution 42 (2): 362-372. DOI: 10.1016/j.ympev.2006.07.003

Sofradžija A. 2009. Slatkovodne ribe Bosne i Hercegovine. [Freshwater fishes of Bosnia and Herzegovina.] Vijeće Kongresa bošnjačkih intelektualaca, Sarajevo, Bosnia and Herzegovina. [In Bosnian.]

Šanda R., Bogut I., Vukić J. 2008a. Novi podaci o ihtiofauni slijeva donje Neretve i okolnih kraških polja u Bosni i Hercegovini. [New information on the ichthyofauna from the lower Neretva catchment and surrounding karst fields in Bosnia and Herzegovina.] Pp. 119-125. In: Uzgoj slatkovodne ribe, stanje i perspektive. [Freshwater fisheries, condition and perspectives.] Hrvatska gospodarska komora, Zagreb, Croatia. [In Croatian.]

Šanda R., Bogut I., Doadrio I., Kohout J., Perdices A., Perea S., Šedivá A., Vukić J. 2008b. Distribution and taxonomic relationships of spined loaches (Cobitidae, Cobitis) in the River Neretva basin, Bosnia and Herzegovina. Folia Zoologica 57 (1-2): 20-25.
Škrijelj R., Lelo S., Drešković N., Sofradžija A., Trožić-Borovac S., Korjenić E., Lukić-Bilela L., Mitrašinović-Brulić M., Kotrošan D., Šljuka S., Gajević M., Karačić J. 2013. Crvena lista faune Federacije Bosne i Hercegovine. Knjiga 3. [Red list of Federation of Bosnia and Herzegovina. Book 3.] EU Greenway, Sarajevo, Bosnia and Herzegovina. [In Bosnian.] http://www.ekoakcija.org/files/Crvena\%20 lista\%20Faune\%20FBiH.pdf

Švob T., Kilalić T. 1972. Prilog morfologiji digestivnog sistema nekih salmonida i ciprinida rijeke Neretve. [Contribution to the morphology of the digestive system of some salmonids and cyprinids of the Neretva River.] Ichthyologia 4 (1): 83-88. [In Serbian.]

Tutman P., Glamuzina B., Bartulović V., Buntić I. 2002. Endemična ihtiofauna močvare Hutovo Blato. [Endemic ichthyofauna of Hutovo blato wetland.] Pp. 45-48. In: Buntić I. (ed.) Nova politika gospodarenja vlažnim područjima Hutova Blata. Završni simpozij LIFE Projekta LIFECY 99/BIH/035. LIFE, Mostar, and Ministarstvo graditeljstva, prostornog uređenja i zaštite okoliša HNŽ-K, Mostar, Bosnia and Herzegovina. [In Croatian.]

Tutman P., Glamuzina B., Dulčić J. 2008. Threatened fishes of the world: Chondrostoma knerii Heckel, 1843 (Cyprinidae). Environmental Biology of Fishes 83 (2): 209-210. DOI: 10.1007/s10641-007-9320-8

Tutman P., Glamuzina B., Dulčić J. 2013. Monitoring stanja biljnog i životinjskog svijeta nakon požara, devastacije i raspuštanja lovočuvarske službe u Parku prirode Hutovo blato (Donji tok rijeke Neretve) poglavlje fauna riba. [Monitoring the state of flora and fauna after the forest fire, devastation and dissolution of game-keeping services in Hutovo Blato (lower Neretva River) - Chapter fish fauna.] Ministarstvo okoliša i turizma Federacije Bosne i Hercegovine, Sarajevo, Bosnia and Herzegovina. [In Croatian.]

Tutman P., Glamuzina B., Dulčić J., Bartulović V., Hasković E. 2009. Endemic fish fauna of the Hutovo Blato wetland (Neretva River basin, Bosnia and Herzegovina) and their conservation status. Pp. 69. In: Kontautas A. (ed.) 13th European Congress of ichthyology. Klaipedos universitetas, Klaipeda, Lithuania.

Tutman P., Glamuzina B., Dulčić J., Zovko N. 2012. Ihtiofauna močvare Hutovo Blato (donji tok rijeke Neretve, Bosna i Hercegovina): stanje i ugroženost. [Ichthyofauna of the Hutovo Blato wetland (lower Neretva River, Bosnia and Herzegovina): Status and vulnerability.] Croatian Journal of Fisheries 70 (4): 169-185.

Tutman P., Hamzić A., Hasković E., Dulčić J., Pavličević J., Glamuzina B. 2016. Neretva rudd, Scardinius plotizza Heckel et Kner, 1858 (Cyprinidae), endemic fish species of the Adriatic watershed; biologicalecological and conservation traits. Annales, Series Historia Naturalis 26 (2): 185-190. DOI: 10.19233/ ASHN.2016.16 
Tutman P., Matić-Skoko S., Hamzić A., Dulčić J., Glamuzina B. 2018. Life history traits of Neretva roach Rutilus basak (Heckel, 1843) (Pisces, Cyprinidae): Biological and ecological contribution for biodiversity conservation of freshwater fish. Croatian Journal of Fisheries 76 (2): 66-71.

Vuković T. 1963. Ribe Bosne i Hercegovine. [Fishes of Bosnia and Herzegovina (determination key).] IGKRO Svjetlost, Sarajevo, Yugoslavia. [In Serbo-Croatian/ Croato-Serbian.]

Vuković T. 1964. Prilog poznavanju prirodne hibridizacije ciprinida u vodama Livanjskog polja. [Contribution to the knowledge of natural hybridization of cyprinids in the waters of Livanjsko field.] Godišnjak Biološkog instituta Univerziteta u Sarajevu 17: 199-206. [In Serbo-Croatian/Croato-Serbian.]

Vuković T. 1977. Ribe Bosne i Hercegovine. [Fishes of Bosnia and Herzegovina.] IGKRO Svjetlost, Sarajevo, Yugoslavia. [In Serbo-Croatian/Croato-Serbian.]

Vuković T., Ivanović B. 1971. Slatkovodne ribe Jugoslavije. [Freshwater fishes of Yugoslavia.] Zemaljski muzej Sarajevo, Yugoslavia. [In SerboCroatian/Croato-Serbian.]

Vuković N., Vuković T. 1974. Morfologija mozga nekih ciprinida iz voda Jugoslavije. [The brain morphology of some cyprinids from Yugoslavian waters.] Ichthyologia 6 (1): 125-141. [In Serbo-Croatian/ Croato-Serbian.]

Vuković N., Vuković T., Sekulović T. 1970. Težina srca i mozga kod nekih vrsta ciprinida iz Skadarskog jezera i reke Bune. [The weight of the heart and the brain in some cyprinids from Skadar Lake and the Buna River.] Ichthyologia 2 (1): 143-154. [In Serbo-Croatian/ Croato-Serbian.]

Vuković T., Sofradžija A. 1987. Endemična ihtiofauna Bosne i Hercegovine i problemi njene zaštite. [The endemic ichthyofauna of Bosnia and Herzegovina and the problems of its protection.] Pp. 39-43. In: Vuković T. (ed.) Zaštita endema u živom svijetu Jugoslavije. Posebna izdanja Odjeljenja prirodnih i matematičkih nauka, Akademije nauka i umjetnosti Bosne i Hercegovine, Sarajevo, Yugoslavia. [In SerboCroatian/Croato-Serbian.]

Zupančič P. 2008. Rijetke i ugrožene slatkovodne ribe jadranskog slijeva Hrvatske, Slovenije i Bosne i Hercegovine. [Rare and endangered freshwater fishes of Adriatic watershed of Croatia, Slovenia and Bosnia and Herzegovina.] Narodna univerzitetna knjižnica, Ljubljana, AZV d.o.o., Slovenia. [In Croatian.]

Received: 11 July 2018 Accepted: 27 December 2018 Published electronically: 15 June 2019 